Special issue of the International Conference on Computational and Experimental Science and Engineering (ICCESEN 2014)

\title{
Effects of Ethephon on the Hemolymph Metabolites of the Greater Wax Moth Galleria mellonella L. (Lepidoptera: Pyralidae)
}

\author{
H. Altuntaş*
}

Anadolu University, Faculty of Science, Department of Biology, Eskişehir, Turkey

\begin{abstract}
Ethephon (ETF), one of the plant growth regulators, is used in agricultural systems as a valuable tool due to its property of regulating fruit maturation. Here, we aimed to investigate the toxic effects of ETF on the hemolymph metabolites of the greater wax moth, G. mellonella which is an experimental animal and a serious pest in wax. Different doses of ETF $(250-390 \mu \mathrm{g} / 5 \mu \mathrm{l})$ were injected with force feeding method to the last instars and the effects of ETF on the level of hemolymph protein, lipid, and glucose were estimated spectrophotometrically at 24 and $48 \mathrm{~h}$ after treatments. The levels of protein, glucose, and lipid in hemolymph showed dose- and time-dependent changes. These results indicated that treatment with ETF may result in significant physiological changes in pests. Consequently, it is likely that ETF can be a promising agent for use in integrated pest management programs as ecofriendly biopesticides.
\end{abstract}

DOI: 10.12693/APhysPolA.128.B-182

PACS: 89.60.-k

\section{Introduction}

Plant growth regulators (PGRs), playing role in the regulatory mechanisms of plants growth and development, are widely used for increase of agricultural production. Evidence from early studies has shown that various PGRs cause the death of insects by their toxic impacts such as changes in biological and biochemical characteristics [1-4]. ETF, one of the PGRs, is an organophosphorus pesticide and used in agricultural systems to regulate fruit maturation [5]. Several studies have demonstrated mutagenic, teratogenic, and biochemical effects of ETF on human and higher animals [6-8]. However, similar studies are very limited related with biological effects of ETF on insects particularly pests [9]. No studies determining the toxicological, biological, and physiological effects of ETF on the model organism Galleria mellonella, have been found in open literature. In the current study, the total protein, lipid, and glucose content of hemolymph from G. mellonella larvae were evaluated with respect to effective ETF doses.

\section{Material and methods}

\subsection{Insect rearing, bioassays and hemolymph collection}

Galleria mellonella colony was reared on honeycomb at $27 \pm 1{ }^{\circ} \mathrm{C}, 60 \pm 5 \% \mathrm{RH}$, and photoperiod of $12: 12$ (L:D). The technical ETF (Sigma, St. Louis, MO) was used and dissolved in deionized water. Selected larvae which were $0.16 \pm 0.01 \mathrm{~g}$ in weight were force fed by applying $5 \mu \mathrm{l}$ of different effective doses of ETF solution $(250,300,330$,

*e-mail: hyalcitas@anadolu.edu.tr
360 , and $390 \mu \mathrm{g} / 5 \mu \mathrm{l})$ on esophagus with a Hamilton syringe (22 gauges). Hemolymph samples from force fed larvae were obtained by piercing the third proleg with micro-scissors at 24 and $48 \mathrm{~h}$ post treatments. Ten microliters of hemolymph from each individual larva were collected into a micro centrifuge tube. Samples were immediately mixed to $0.001 \mathrm{mg}$ 1-phenyl-2-thiourea and frozen at $-80^{\circ} \mathrm{C}$ until assays. Prior to analysis, all hemolymph samples were centrifuged at $10,000 \mathrm{~g}$ for $5 \mathrm{~min}$ at $4^{\circ} \mathrm{C}$.

\subsection{Determination of total protein, lipid and glucose}

Total protein of each hemolymph sample from larvae was estimated by the method of Bradford [10], using bovine serum albumin (BSA) (Merck, Darmstadt, Germany) as standard. The optical density of the mixture was measured using a spectrophotometer (Shimadzu UV1601, Tokyo, Japan) at $695 \mathrm{~nm}$. Total lipid content of each hemolymph sample from larvae was determined by the vanillin-phosphoric acid method of Van Handel [11] and measured with spectrophotometer at $525 \mathrm{~nm}$. The corn oil solution (Merck) was also used for the standard curve. An anthrone test developed by Van Handel [12] was used for the detection of glucose in the hemolymph obtained from larvae using glucose (Merck) as standard and absorbance was measured at $625 \mathrm{~nm}$. All assays were replicated four times with ten larvae in each treatment ( $n=40$ per treatment).

\subsection{Statistical analysis}

Dose-related changes in the means of total metabolites were checked to normality of data distribution. One-way analysis of variance (Tamhane $\mathrm{T} 2$ post hoc tests) and $t$-test (24 and $48 \mathrm{~h}$ ) were used to compare means and subsequently significant differences were determined using SPSS program (version 18.0 for Windows, SPSS Science, Chicago, IL). Results were considered statistically significant when $P<0.05$. 


\section{Results}

Total protein level in larval hemolymph increased upon exposure to all doses of ETF ( F: 52.030; $d f: 5,66 ; P$ : $0.000)$ at $24 \mathrm{~h}$ when compared with control group. However, at $72 \mathrm{~h}$, total protein content of ETF treated groups decreased at $>250 \mu \mathrm{g} / 5 \mu \mathrm{l}$ doses $(F: 47.395 ; d f: 5,66$; $P$ : 0.000). Total lipid content of ETF treated groups was significantly lower than that of the control group $24 \mathrm{~h}$ $(F: 44.717 ; d f: 5,66 ; P: 0.000)$ and $48 \mathrm{~h}(F: 10.860$; $d f: 5,66 ; P: 0.000)$ except for the significant increase at
$300 \mu \mathrm{g} / 5 \mu \mathrm{l}$ doses at $24 \mathrm{~h}$. Furthermore, lipid concentration of control and treated groups decreased at two time points $(P<0.05, t$-test $)$. Similar results were also observed in total glucose content of larvae. There was also a significant decrease in all doses of ETF treated groups at $24 \mathrm{~h}(F: 232.158 ; d f: 5,66 ; P: 0.000)$ and $48 \mathrm{~h}(F$ : $147.205 ; d f: 5,66 ; P: 0.000)$ with respect to the control and this trend in decline was determined between two time points $(P<0.05, t$-test $)$ (Table).

TABLE

ETF-related changes in total protein, lipid, and glucose content (mean $\pm \mathrm{SE},[\mu \mathrm{g} / \mu \mathrm{l}])$ of $G$. mellonella larvae.

\begin{tabular}{c|c|c|c|c|c|c}
\hline \hline \multirow{2}{*}{$\begin{array}{c}\text { ETF doses } \\
{[\mu \mathrm{g} / 5 \mu \mathrm{l}]}\end{array}$} & \multicolumn{2}{|c|}{ Protein } & \multicolumn{2}{c|}{ Lipid } & \multicolumn{2}{c}{ Glucose } \\
\cline { 2 - 6 } & $24 \mathrm{~h}$ & $48 \mathrm{~h}$ & $24 \mathrm{~h}$ & $48 \mathrm{~h}$ & $24 \mathrm{~h}$ & $38 \mathrm{~h}$ \\
\hline control & $5.76 \pm 0.34 a x$ & $11.44 \pm 0.15 a y$ & $4.82 \pm 0.09 a x$ & $2.53 \pm 0.08 a y$ & $5.32 \pm 0.06 a x$ & $3.21 \pm 0.09 a y$ \\
250 & $10.02 \pm 0.39 b x$ & $12.25 \pm 0.34 a y$ & $5.05 \pm 0.05 a x$ & $2.45 \pm 0.07 a y$ & $3.27 \pm 0.14 b x$ & $1.83 \pm 0.09 b y$ \\
300 & $8.98 \pm 0.26 c x$ & $9.39 \pm 0.19 b x$ & $6.01 \pm 0.18 b x$ & $2.24 \pm 0.08 a b y$ & $2.98 \pm 0.02 b x$ \\
330 & $8.48 \pm 0.29 d x$ & $8.37 \pm 0.15 c x$ & $3.87 \pm 0.09 c x$ & $2.03 \pm 0.06 b c y$ & $2.67 \pm 0.013 b x$ \\
360 & $7.73 \pm 0.09 e x$ & $10.21 \pm 0.09 d y$ & $3.62 \pm 0.17 c x$ & $1.96 \pm 0.11 b c y$ & $1.78 \pm 0.01 c x$ & $1.60 \pm 0.07 b y$ \\
390 & $7.69 \pm 0.16 e x$ & $10.09 \pm 0.18 d y$ & $3.69 \pm 0.20 c x$ & $1.98 \pm 0.06 c y$ & $1.60 \pm 0.07 c x$ & $0.84 \pm 0.01 d y$ \\
\hline
\end{tabular}

*Results not significantly different are followed by the same letter, $x-y$ for each metabolite, $P>0.001 ; t$-test within each row and $a-e$ between two time points, $P>0.05$; Tamhane test - within each column.

\section{Discussion and conclusion}

A gradual decrease, particularly at two time points and at higher doses of ETF treatment, in the total lipid and glucose levels in larval hemolymph were observed in present study. Similar results were also determined in several studies related with gibberellic acid $\left(\mathrm{GA}_{3}\right)$, one of the PGR, for Galleria mellonella and some other insect species $[1,4]$. These changes may be related with the use of lipids and glucose in cell repair and lipoprotein formation, which will be used to repair damaged cell and tissue organelles depending on ETF-induced stress. This case indicated that increasing doses of ETF cause toxic effects on the pest larvae similar to that of seen in higher animals [6-8]. On the other hand, total protein content showed different changes between two time points in larval hemolymph upon exposure to ETF. First, an increase in level was observed and then protein amount of larval hemolymph decreased with respect to controls (see Table). These results also support a previous study of Uçkan et al. [4] who found an increase in total protein in hemolymph of $G$. mellonella larvae upon exposure to $\mathrm{GA}_{3}$. Furthermore, Raouf and Girgis [6] reported that different doses of ETF caused a reduction in total protein content in the liver and brain of mice dams and fetuses. The current and other studies emphasized that increasing protein catabolism was related with a physiological adaptability to compensate for ETF-induced stress. Because animals require high energy under stress conditions, the energy demand may have led to the stimulation of protein catabolism. In conclusion, data obtained here indicate that ETF may adversely affect pests via biochemical alterations. Therefore, this study will con- tribute to ecotoxicological information and usability of ETF in integrated pest management programs.

\section{Acknowledgments}

The research is supported by Anadolu University Scientific Research Project Commission, of Turkey (No. 1305F101).

\section{References}

[1] R. Kaur, P.J. Rup, Entomon 28, 89 (2003).

[2] F. Uçkan, A. Tüven, A. Er, E. Ergin, Ann. Entomol. Soc. Am. 101, 593 (2008).

[3] F. Uçkan, İ. Haftacı, E. Ergin, Ann. Entomol. Soc. Am. 104, 77 (2011)

[4] F. Uçkan, Z. Öztürk, H. Altuntaş, E. Ergin, J. Entomol. Res. Soc. 13, 1 (2011).

[5] H. Kidd, D.R. James, The Agrochemicals Handbook, 3rd ed., Royal Society of Chemistry Information Services, Cambridge 1991, p. 10.

[6] A.A. Raouf, S.M. Girgis, Global Veterinaria 6, 251 (2011).

[7] J.E. Haux, O. Lockridge, J.E. Casida, Chem. Res. Toxicol. 15, 1527 (2002).

[8] Extension Toxicology Network (EXTOXNET) Pesticide Information Profile, Ethephon 1995.

[9] A.J. Payne, J.S. Kays, J. Econ. Entomol. 71, 5 (1978).

[10] M.M. Bradford, Ann. Biochem. 72, 248 (1976).

[11] E. Van Handel, J. Amer. Mosq. Cont. Assoc. 1, 302 (1985).

[12] E. Van Handel, J. Amer. Mosq. Cont. Assoc. 1, 299 (1985). 